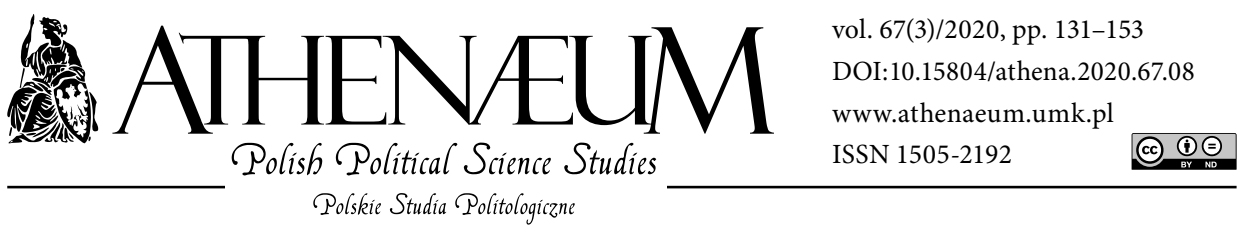

\title{
TOWARDS A REDEFINITION OF ISLAMIC SUICIDE TERRORIST'S MOTIVATION: AN "ALTRUISTIC" TERRORIST MODEL
}

\author{
ZMIERZAJACC KU REDEFINICJI MOTYWACJI ISLAMSKICH \\ TERRORYSTÓW SAMOBÓJCÓW: \\ MODEL „ALTRUISTYCZNEGO” TERRORYSTY
}

Zbigniew Małysz*๑

\begin{abstract}
The article aims at a redefinition of Islamic suicide terrorist's motivation. It describes the basic determinants and conceptualizations of terrorism and discusses major theories and explanations of that phenomenon from an individualistic and sociocultural perspective. Due to the fact that suicide terrorism is a very distinct and narrow subcategory of terrorism, the paper addresses the questions of Why it is unique? and in What ways it is distinct from ("normal") terrorism in general? Given the absence of convincing psychological, sociological and educational evidence that terrorists (and especially suicide terrorists) differ in any particular way from the normal population, the author has developed and proposed an "altruistic" suicide-terrorist model.

The proposed model treats suicide terrorism as a process of continuous communication/
\end{abstract}

Niniejszy artykuł ma na celu zredefiniowanie motywacji islamskich terrorystów samobójców. Opisuje on podstawowe determinanty i koncepcje terroryzmu oraz omawia główne teorie i wyjaśnienia tego zjawiska z perspektywy indywidualistycznej i społeczno-kulturowej. $\mathrm{Z}$ uwagi na fakt, że terroryzm samobójczy jest bardzo odrębną i wąską subkategorią terroryzmu, w artykule podjęto próbę odpowiedzi na następujące pytania: Dlaczego jest on wyjatkowy? i W jaki sposób różni się od („zwykłego”) terroryzmu? Biorąc pod uwagę brak przekonujących dowodów psychologicznych, socjologicznych i edukacyjnych na to, że terroryści (a zwłaszcza terroryści samobójcy) różnią się w jakikolwiek sposób od normalnej populacji, autor opracował i zaproponował model „altruistycznego” terrorysty samobójcy.

* The Maria Grzegorzewska Pedagogical University in Warsaw, Institute of Pedagogy. 
education between the terrorist and his/her reference group in which psychosocial bonds are developed between the individual and the terrorist organization. The process is determined by: (1) an erroneous understanding of jihad, (2) the existence of conducive external conditions, such as frustration underpinned by poor living standards and a sectarian mentality negating the outside world and its values, and (3) a high level of altruism (and in particular reciprocal altruism) in would-be suicide bombers.

Keywords: suicide terrorist model (redefinition); (reciprocal) altruism; Islam; group processes; reference group; education
Proponowany model traktuje terroryzm samobójczy jako proces ciągłej komunikacji między terrorystą a jego/jej grupą odniesienia, w którym rozwijane są więzi psychospołeczne między jednostką a organizacją terrorystyczną. Proces ten determinowany jest przez: (1) błędne zrozumienie dżihadu, (2) istnienie sprzyjających warunków zewnętrznych, takich jak frustracja spowodowana złym poziomem życia i mentalności sekciarskiej negującej świat zewnętrzny i jego wartości, oraz (3) wysoki poziom altruizmu (a zwłaszcza altruizmu odwzajemnionego) u potencjalnych zamachowców samobójców.

Słowa kluczowe: model terrorysty-samobójcy (redefinicja); altruizm (odwzajemniony); islam; procesy grupowe; grupa odniesienia; edukacja

\section{INTRODUCTION}

Terrorism has become a multidimensional activity with widespread and numerous actors or creators of terror/violence. When discussing terrorism and its modus operandi, it should be borne in mind that it typically represents an activity of long duration which needs careful and secretive planning, preparation, and execution, akin to special military forces and services. The main perpetrators of terror worldwide are terrorist organizations (e.g., Al-Qaeda, the Islamic State, Boko Haram, Al-Fatah, Hamas, Irish Republican Army, Euskadi Ta Askatasuna, etc.), which strike to achieve some more or less precisely defined, predominantly political, but also economic, military, and even religious, goals. The second category of terrorists consists of "lone wolves" motivated by an individual understanding of social justice or ideology. The third and most interesting category of terrorists are organizations and "semi-lone wolves" enticed, trained and equipped covertly by states or their intelligence agencies (as in the Ukrainian crisis). The most distinct (narrowest) and academically interesting subcategory of the above three types of actors are suicide terrorists, who are the subject matter of the presented paper. 


\section{BASIC DETERMINANTS AND CONCEPTUALIZATIONS OF TERROR AND TERRORISM}

The key to understanding terrorism is an understanding of the basic determinants of human aggression, violence, and their human dimensions. Terrorism may be defined as the use of terror (extreme physical aggression/violence towards certain social groups) to achieve political, economic, or military goals. However, this definition is very narrow and does not cover some important pre-terror conditions.

In the process of defining terrorism one should be aware of at least four important issues characterizing modern-day terrorism:

1) Diversity and a lack of focus: In different geographic regions and at different times, different acts may be deemed "terrorist"; it is almost impossible to formulate a general definition of "terrorism" due to the fact that every terrorist has his/her own specific goals and set of beliefs.

2) Point of view: Acts which may be deemed "terrorist" by one population may be perceived as heroism, guerilla warfare, or freedom fighting by another. There is also a strong tendency to romanticize " "unheroic»terrorist acts" committed by important political and social or (in extreme circumstances) military figures struggling against the "barbaric others" attacking women and children.

3) Escalation of attacks: Each new terrorist attack is supposed to be larger, louder, and more powerful than the previous one as terrorists need to shock public opinion and want their actions to attract increasing attention from society and the mass-media (which gives rise to the problem of the domestication of terrorism).

4) Diversity of motivations of terrorist organizations and lone wolves: David C. Rapoport has developed his famous concept of four waves of terrorism (Rapoport, 2004): the first one is anarchistic ("pro-democratic"), the second one is anticolonial, the third one represents "New Left" terrorism, and the fourth one is Islamic ("jihadist") [this proposition is favored by researchers and taught around the world - Z.M.]. Due to rapid political changes around the world and emerging unconventional ways of engaging in political conflicts (e.g., hybrid warfare), it has been proposed that a fifth wave, namely, state terrorism, should be added: In today's multipolar world of "liquid modernity" (see: Bauman, 2000), in the wake of the Cold War threat of atomic annihilation, the use of force by one state against 
others without starting a war is a very cost-effective solution to resolve "unsolvable" problems (see: the Ukrainian crisis and "little green men", Latin America in the 1980s, etc.). One should be aware that this wave differs in many ways from the four preceding ones. Such terrorist attacks are well coordinated and planned and carried out by well-equipped and trained special forces acting against military and political personnel on foreign ground without declaring war. Typically, the assailants will not directly attack civilian population and their actions are based on good or very good intelligence (compare: Karolczak, 2010).

In light of the above problems, this paper defines terrorism as a goaloriented use of violence (terror) in the form of guerrilla warfare (hit-and-run tactics) by individuals, groups, organizations, or states against their "enemies" including civilians, military and institutional personnel, as well as critical civilian and/or military infrastructure without pre-existing and legalized state/ declaration of war. This activity is designed to force the policy-makers and society to perform or discontinue certain actions, to obtain mass obedience (by manipulation of the perception of enemies), or to acquire political power without declaring war.

\section{ORIGINS OF TERRORISM}

Past and present research divides theories of terrorism into two groups: individualistic or human-oriented and sociocultural; the latter are focused on interactions between social and cultural factors, certain combinations of which may potentially incite terrorism in some groups and societies.

The main individualistic theories involve the following underlying causes, motives, or explanations of terrorism (cited after: Bolechów, 2010):

- developmental psychopathology or disturbances in psychophysiological functions; mostly avitaminosis, negative character traits, and psychopathy - relevant research findings concern: congenital conditions and avitaminosis (Lombroso, 1870), vestibular defects of the inner ear (Hubbard, 1983), "normality" of terrorists (Crenshaw, 1981), absence of a specific psychopathology in terrorists (McCauley \& Segal, 1987; Ferracuti, 1982), antisocial personality disorder (Cooper, 1977, 1978; Taylor, 1988), narcissistic psychopathy (Hamden, 2002), altruistic suicide (Durkheim, 1897, 
2011), and psychopathology resulting from participation in a terrorist organization (Taylor, 1988),

- model of rational choice based on game theory - based on the equation: participation in a terrorist organization $=$ personal profit + group profit - costs (Gupta, 2005), game theory as a useful tool in terrorism research (Sandler \& Arce, 2003), the problem of a "monolithic" view of terrorism (Crelinsten, 1988), the relative nature of terrorist rationality (Ganor, 2005), the proposition that terrorists think rationally but believe irrationally (Goertzel, 2002),

- terrorist personality or mentality (types) - this construct has been discussed in, e.g., Horgan (2003), Reid (2002), Laqueur (2001), and Fetscher \& Rohrmoser (1981): a) extraverted type vs.b) neurotically-hostile type,

- need for strong stimulation (temperamental sensation seeking) - Levine (1999), Crenshaw (1986): a) individualistic vs. b) group,

- “authoritarian extremist personality" - Ferracuti \& Bruno (1981),

- low socioeconomic status - partly falsified by Sageman (2004),

- social influence and tendency to increase socioeconomic status - Sageman (2004), Post, Sprinzak, \& Denny (2003),

- psychodynamics and its influence on human life - involving hostility between sons and fathers based on the Freudian Oedipal complex (Feuer, 1969), projective identification (Perlman, 2002), narcissism (Rothman \& Lichter, 1982), narcissistic disappointment and rage (Pearlstein, 1991), identity and its crisis (Taylor \& Louis, 2004), the frustration-aggression hypothesis (Bandura, 1973; Berkowitz, 1989), and the relative deprivation hypothesis (Gurr, 1970); also see contributions by Kohut (1971), Crayton (1983), Morf (1970), Volkan (1997), Robins \& Post (1997), Böllinger (1981), Moghaddam (2006), Gallimore (2002).

From the sociocultural perspective, the most significant explanations involve (cited after: Bolechów, 2010):

- social learning theory - Bandura $(1973,1986)$, Oots \& Wiegele (1986),

- social marginalization of the reference group (its culture and members) - Ardila (2002),

- cultural "pro-terrorist" determinants (on a continuum between individualism and/vs. collectivism) - Staub (2004), Weinberg \& Eubank (1994), Lawal (2002), Moghaddam (2006),

- cultural context and group identity - Caracci (2002), 
- radical social changes and reactions to their emergence - Waldmann (2005),

- intergroup conflict - Sherif (1966), Volkan (1988, 1992), Olweean (2002), Kressel (2002), Brewer (1999), Gaylin (2003), Post (2007), Staub (2004), Girard (2004), Lerner (1980),

- radical social changes - Stevens (2002), Stern (2003), Münkler (2004), Selengut (2003), Tajfel \& Turner (1986), Moghaddam \& Harré (1996), Vygotsky (1978),

- memetics/memeplexes of terror and terrorism - Dawkins (1976),

- initial conditions and detonators (radicalization and escalation) Hacker (1983), Shaw (1986), Borum (2003), Sprinzak (1998), Moghaddam (2005), Drummond (2002),

- processes - Horgan $(2005,2014)$, Bolechów $(2002,2010)$.

\section{UNIQUE CHARACTERISTICS OF SUICIDE TERRORISM}

Taking into consideration the above-mentioned theories concerning terrorism and its influence on normal human life, the widespread occurrence of suicide attacks is quite surprising. Indeed, suicide terrorism is very special in at least six respects:

1. It is a relatively new kind of terrorism originating from Lebanon (from the 1980s);

2. A relatively small number of people ("actors") participate in suicide attacks (currently the numbers of such attacks are growing and they are increasingly better prepared);

3. Suicide attacks are performed almost exclusively by Muslims;

4. Such attacks are very spectacular and attract the attention of the mass media;

5. In the public mind they are associated with the religious sphere;

6. Such activity is alogical within the European sociocultural framework (see: Horgan, 2008, 2014; Bolechów, 2010; Zimny, 2006, 2017).

For a long time, suicide attacks have been explained through (see: Bolechów 2010; Zimny, 2006, 2017):

- religious fundamentalism,

- modeling behavior,

- desperation of suicide terrorists and their social surroundings, 
- the perception of self as a group or individual "oppressed by others and selected to carry out an important mission",

- Émile Durkheim's theory of suicide, including the following motivations: selfish (linked to trauma or disease), fatalistic (brought about by peer pressure), altruistic (associated with integration with one's group, where suicide is perceived as superior to attacking others), and anomic (resulting from an absence, confusion, conflict in the norms of a society or lack of strong social ties to other people),

- cultural violence (redefined meaning of violence with aggression and violence towards others being a source of pride),

- ideology,

- personal and family benefits (prestige),

- ethos of martyrdom,

- effectiveness of the strategy.

The theories given above are very popular and widely believed to be useful for predicting and explaining terrorist attacks around the world. But from the psychological/psycho-pedagogical perspective they do not explain satisfactorily the following issues concerning suicide terrorism:

1) Why is there "only a handful of men involved in terrorist activity" amongst millions of people? (Bolechów, 2010, p. 98).

2) Why are there so few terrorists who are capable of a suicide attack?

3) What explains the fact that among the legions of terrorists, "only a handful of Muslims are carrying out suicide attacks"?

\section{REDEFINITION OF ISLAMIC SUICIDE TERRORIST MOTIVATION}

Prior to embarking on an effort to redefine Islamic suicide terrorist motivation, one should specify the prerequisites of redefinition:

1. Humans are raised by and emotionally invested in the reference groups to which they belong, such as a clan, tribe, community, nation, or even an imaginary entity; therefore, they act, feel, and think accordingly (see: Bolechów, 2010, p. 75; Giddens, 2004; Sztompka, 2002).

2. Transmission of values and "humanity" takes place in society within the culture of the group or community (see: White, 1977; Hurrelmann, 1989; Erikson, 1950, 1968; Erikson \& Erikson, 1997; Cooley, 1902; Mead, 
1934; Harris, 1998; Ochs, 1988; Schieffelin, 1990; Schieffelin, Woolard, \& Kroskrity, 1998).

3. Humans always act (more or less consciously and intentionally) in such a way as to defend their reference group, e.g., family, friends, tribe, caste, class, nation, etc. (see: Aronson, 2011; Aronson, Wilson, \& Akert, 2010; Aronson et al., 2015; Austin \& Worchel, 1979; Bales, 1950; Doise \& Palmonari, 1984; Sorokin, 1925; Parsons, 1964; Merton, 1968[1949]; Turner, 1994).

As stated above, there is no significant psychological or socio-educational evidence that terrorists (or suicide terrorists) differ in any particular way from the normal population. Previous theories and models endeavored to explain and predict terrorism through different individual and sociocultural conditions, but they failed to give a clear answer to the question as to: What distinguishes suicide terrorists from the normal population? - and: Why? There are still no convincing theoretical or empirical findings identifying the values and conditions creating terrorists, and in particular - suicide terrorists.

To fill in the aforementioned research gap, the author has developed and proposed an "altruistic" terrorist model, according to which suicide terrorism is determined by:

1. An erroneous understanding of jihad (in the case of Islamic terrorists),

2. The existence of conducive external conditions, such as frustration underpinned by poor living standards and a sectarian mentality negating the outside world and its values,

3. A high level of altruism, and especially reciprocal altruism, in (wouldbe) suicide bombers.

These three preconditions may enable the initiation of group processes developing psychosocial bonds between an individual and his/her reference group (in this case, a terrorist organization) which finally lead to a suicide attack carried out as an act of perceived defense of the reference group (the suicide bomber intends to increase the chances of survival of that group) (Sic!).

\section{1) ERRONEOUS UNDERSTANDING OF JIHAD}

The explanation of the first point is strictly sociocultural. Briefly, it should be noted that Islam is a very peaceful religion and calls for continuous improvement through efforts to please Allah, collectively known as jihad (Aktan, 2007, p. 43).

The Qur'an mentions four types of ideal people to be emulated (Women 4:69): the prophets, the affirmers of truth (siddiq), the martyrs (shahid, also translated 
as "witnesses"), and the righteous (salih) (Yüceoğlu, 2007, p. 105). Martyrdom is imbued with spirituality, but the key issue is the individual's intention (Yüceoğlu, 2007, p. 106). There are three kinds of martyrdom: perfect, of this world, and of the afterworld. A perfect martyr should profess Islam, possess full mental faculties (be a sane adult) and be ritually clean; furthermore, death must occur for a just cause rather than as a punishment, retaliation for a sinful deed (outside the scope of blood money), or by accident; also injured individuals evacuated from the battlefield are excluded (Yüceoğlu, 2007).

According to Islam law, military actions undertaken by fighters should be triggered by a state of war, directed against enemy militants, and dependent on a prior damage done by the enemy (Güneş, 2007). In the case of death in combat with infidels, participation in jihad entails very attractive gratification for men in the form of the houris. On the other hand, jihadi fighters killed in battle by a woman are said to be barred from salvation (Sic!).

Finally, it should be borne in mind that Islamic law allows the possibility of different, competing interpretations of faith by imams and the imposition of fatwas (in the Roman Catholic Church there is only one interpretation of faith, ultimately decided by the Pope; in other Christian denominations the divisions are not as common and profound, and the proponents of different interpretations are able to coexist peacefully; finally, in Christianity there exists a strong ecumenical tendency not present in Islamic denominations). Moreover, a considerable body of research also indicates that this situation has enabled the growing importance of Islamic extremist and fundamentalist movements (Zimny, 2006, 2017), and especially Wahhabism, which seems to completely repudiate a non-Islamic way of life (DeLong-Bas, 2004).

\section{2) THE EXISTENCE OF CONDUCIVE EXTERNAL CONDITIONS}

As it was mentioned above, frustration with one's living conditions is a very useful tool in explaining the recent alarming surge of suicide attacks. The classical sociological J-curve model developed by James C. Davies (1962) is extremely helpful in understanding this issue. According to this model, throughout history each community, tribe, nation, society, etc. pursues welfare striving to attain better living and working conditions. This process leads to the emergence of increasing needs (including material goods) which need to be satisfied. Following a relatively long calm period without civil or military unrest accompanied by a gradual improvement in living conditions, a society controlled by an authoritarian ruler/democratic community (e.g., comparing the rule 
of Saddam Hussein Abd al-Majid al-Tikriti in Iraq, Mu'ammar al-Kaddafi in Libya, Muhammad Husni as-Sajjid Mubarak in Egypt, Hafez al-Assad and Bashar Hafez al-Assad in Syria with the situation after their fall; western lone wolves and would-be lone wolves who live in a relatively safe environment and enjoy broad privileges of the Western world compared to the traditional Muslim societies of the Arabian Peninsula and the Middle East) is more likely to engage in a revolution if faced with even a short period of economic deterioration and hardship (e.g., the Second Gulf War, the Islamic Revolution in Egypt or the ongoing war in Syria; the socioeconomic crisis in the West and a lack of assimilation of Muslim communities therefore).

Davies concluded that (1962, p. 5): "Revolutions are most likely to occur when a prolonged period of objective economic and social development is followed by a short period of sharp reversal. People then subjectively fear the ground gained with great effort will be quite lost; their mood becomes revolutionary". This idea is aptly presented in Figure 1 below.

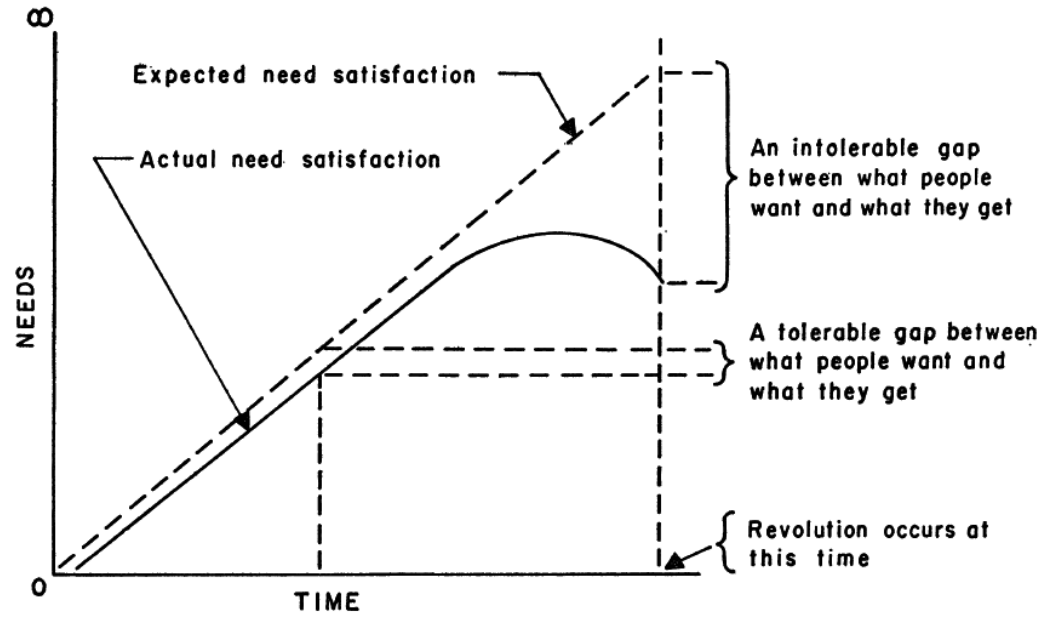

Figure 1. Need for Satisfaction and Revolutions by James C. Davies (Davies' J-curve model)

Source: Davies, 1962, p. 6.

Given the continuum shown in Figure 1 and the conditions in which members of terrorist organizations and lone wolves live, think, feel, and act, they could be treated as members of a sect. A sect is a relatively small group of 
people connected by some ideology, having one or more leaders, gathering more or less regularly, discussing their beliefs and problems, and mostly seeing the outside world as a threat (Stark \& Bainbridge, 1979, 1985; Barker, 1990; Wilson \& Cresswell, 1999). Furthermore in terrorist organizations or sects, "Members need to be integrated, share layers of habitus, hold similar ideas, goals and morals and be committed do the dyad, triad and larger configurations. [bolded by Z.M.]. Hence feelings of commonality and collective purpose need to exist on which to build solidarity in order to achieve group goals. These shared feelings are often created within informal groups through gossip and the mutual identification of group charisma and de-identification with the 'Other'. Secrecy and trust, the intersection between group charisma and stigmatization and minorities of the best and worst are integral to group cohesion, recruitment and retention processes" (Vertigans, 2011, p. 110). One of the most influential researchers of terrorism, John Horgan, claims that potential terrorists and those acting as members of an organization [sect - Z.M.] are characterized by: obedience to authority, dehumanization of their enemies/victims, justification of terrorist actions, routinization of their actions, deindividuation of victims, and, ultimately readiness to change their normal life habitus (see: Horgan, 2008, pp. 140-151).

Finally, it should also be noted that sect members are brainwashed (the highest level of socialization) at the time of their recruitment. Even more importantly, the process of brainwashing continues during periodic meetings and conversations with other sect members (strong socialization function of the group and propaganda). The sect leaders attempt to create a strong belief in their followers that only their teachings are good, acceptable, and trustworthy, while anything else is untruthful, hostile, and disfavored by the God (deity, prophet, sect leader, etc.). As a result, after conversion and confirmation, sect members are very strict in the way they think and act, and behave in a hostile manner to the infidels (the problem of neophytes). The leaders have a tendency to make oversimplifications in conceptualizing the complex world, causing increased radicalization (see: Barker, 1990; Brown, 2001; Cialdini, 2007; Ellul, 1965; Festinger, Riecken, \& Schachter, 1956; Hassan, 1988; Hoffer, 1981; Meerloo, 1956; Singer \& Lalich, 2003; Storr, 1997; Taylor, 2004; Thouless, 1953).

In general, sect members interact with the outside world in three main ways (see: Barker, 1990; Clarke, 2006; Saliba, 2003; Toch, 1965; Wilson, 1961, 1990):

1. Evolutionary - the sect sends preachers to the outside world to peacefully teach outsiders about "the Truth". 
2. Revolutionary - the sect acts as a military or guerrilla force and aggressively fights others to obtain vital resources.

3. Complete avoidance of contact due to indifference, disregard, or hostility towards others - this is the most peaceful way of communication with the main goal being ignorance or defiance of the roles, values, lifestyles, and influence of others/(surrounding) the World.

\section{3) HIGH LEVEL OF RECIPROCAL ALTRUISM}

Within the presented framework, the last but not least distinctive feature of suicide terrorism is a very high level of reciprocal altruism. To better understand the significance of this claim, it should be noted that "[...] sociobiology teaches us that the moral prejudice is bound up with the evolution of altruism. Biologists use the term 'altruism' for any behavior that promotes the reproductive success of another at one's own expense [...]" (Smith, 2011, p. 204). This means that from the sociobiological perspective altruism is understood as a pattern of behavior in which the individual feels and acts to increase the chances of survival and reproduction of other people, even if unrelated (see: Axelrod, 1984; Batson, 1991, 2011; Dawkins, 1976; Kropotkin, 1902; Oord, 2004, 2007, 2010; Oliner \& Oliner, 1995; Wright, 1995). According to cultural anthropology and ethnography, people typically live and operate within their reference cultures, in which they were raised and educated, and with which they are familiar (see: Agar, 1996; Fetterman, 2009; Geertz, 1973; Hammersley \& Atkinson, 2007; Kottak, 2013; Marcus \& Fischer, 1986; Stocking, 1968; Tylor, 1871, 1881; Van Maanen, 1988). This suggests that individuals may be altruistic primarily towards other members of their culture or reference group.

In his seminal work The Genetical Evolution of Social Behavior: I and II, William Hamilton (1964) demonstrated, in the context of evolutionary Darwinism, that the proliferation of donor genes may be achieved through the support of family (reference group members) by begetting, educating and ensuring the safety of offspring (providing a living space for one's relatives), which is known as kin altruism. By analogy, this means that people who are not able to have or nurture and educate their own offspring may achieve genetic success via support given to their more or less broadly defined family (Sic!).

That understanding was extended by Robert Trivers in his widely discussed article The Evolution of Reciprocal Altruism (1971), in which he elaborated on altruism towards nonrelatives. Examining the role of that phenomenon in different species, including primates, cleaning fish and shrimps, birds, and human 
societies, Trivers argued that the rule of reciprocity is omnipresent. According to him, human altruistic attitudes and behaviors toward nonrelatives are linked to genetic proliferation of alleles and are quite common in nature due to their adaptive role - they help to achieve collective safety by means of a relatively small expenditure of effort. Trivers also explained the role of friendship, dislike, moralistic aggression, gratitude, sympathy, trust, suspicion, trustworthiness, some aspects of guilt, dishonesty, and hypocrisy as psychological adaptations helping to regulate the human altruistic system. His model shows that natural selection works against the cheater (non-reciprocator), who is not likely to receive support from others when in danger. It also indicates that the crucial question while examining reciprocal altruism is the problem of revenge (Will I be repaid in kind?). Furthermore, reciprocal altruism may be preferred by cultural systems due to the fact that trust and reciprocity are critical in the process of building social bonds (see: Sztompka, 1999).

Richard D. Alexander (1987) explored in greater detail the relationship between altruists and their reference groups, formulating the concept of "indirect reciprocity". According to him, generous altruists can greatly boost their personal reputation and that of their families, which ultimately is likely to improve their socioeconomic status (cited after: Smith, 2011, p. 206). In some countries and cultures (e.g., Palestine, Afghanistan, and Iraq) people following the social rule of reciprocity may be able to achieve greater benefits for themselves and their families by committing an "altruistic" suicide attack aimed at the oppressive world surrounding them than by staying alive. Social actors who know that their community abides by the social rule of reciprocity are more likely to work for the good of their community because in the long term they simply work for themselves (for the family who carries their genes). If a man or woman dies in a suicide attack, their children, brothers, and sisters are more likely to survive the struggle for limited natural resources'.

${ }^{1}$ We also should remember that in the Islamic world fertility rates are high and due to this fact the gene copies of suicide bomber (carried by their children, parents, brothers and sisters, cousins, etc.) may survive and spread. For instance, a suicide bomber ( $100 \%$ genes) may have 3 children ( $50 \%$ common genes - in total $150 \%$ ), two parents (50\% common genes - in total $100 \%$ ), two brothers and three sisters (25\% common genes - in total $125 \%$ ), which amounts to $375 \%$ copies of genes in the family versus $100 \%$ of genes in the suicide bomber. Ultimately $375 \%$ of the suicide bomber's genes copies remain alive (relatively safe and well protected by the bomber's reference group or a democratic political system). Thus, in terms of gene proliferation the suicide bomber always wins (Sic!). 
In summary, suicide bombers appear to act for the perceived greater good of their generalized reference groups (Sic!). They feel special bonds towards their fellow countrymen or fellow believers. The three factors affecting this process to the greatest extent are: an erroneous understanding of jihad in the religious sphere, conducive external conditions in the sociocultural sphere, and a high level of reciprocal altruism in would-be suicide terrorists. When combined together, these ingredients form a very explosive mixture. Importantly, the bonds between 'suicidists' and their reference groups do not have to be physical - what is sufficient is a platform for the exchange of ideas (e.g., the Internet) and a specific motivation. Furthermore, actual contact with the reference group is not always necessary; the prerequisite is for the prospective suicide bomber to experience a sense of belonging to it (or growing alienation in the culture of the country of residence and misunderstanding of its values).

\section{AN "ALTRUISTIC" TERRORIST MODEL}

A better understanding of the motivation of suicide terrorists would be useful in preventing terrorist attacks. Previous models and theories were concentrated on identifying abnormalities distinguishing such terrorists from the general population, but empirical data show that such an approach has not helped combat global terrorism. Numerous efforts have been undertaken to analyze suicide terrorists (or terrorists in general) in terms of normality and collective actions initiated against more or less clearly specified enemies, but the above-mentioned perspectives also have their limitations (especially as regards lone-wolf motivation). Thus, the present author has developed a novel model in the hope of overcoming these shortcomings.

The interpretation of suicide terrorism proposed herein is dynamic action oriented towards a "total victory" (or, from another perspective: "total annihilation"). Indeed, the suicide quest is interpreted as a dynamic process between a would-be suicide terrorist and his/her reference group. Due to its processual nature, the presented model consists of phases of intensive activity (preparation of an attack) followed by relative quiescence (reconnaissance and prayers preceding the attack), as shown below in Model 1. 


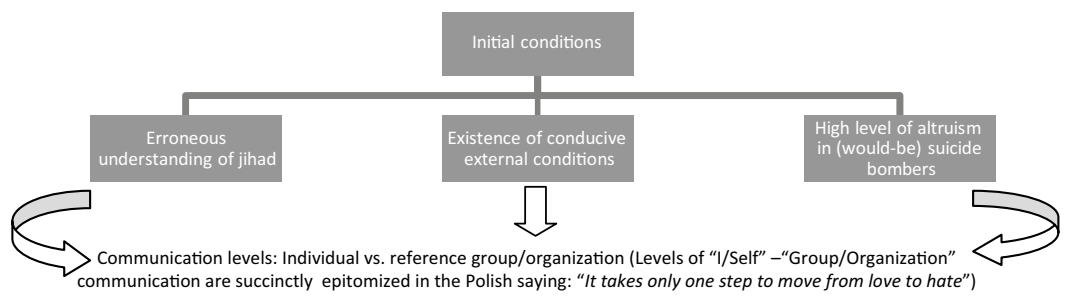

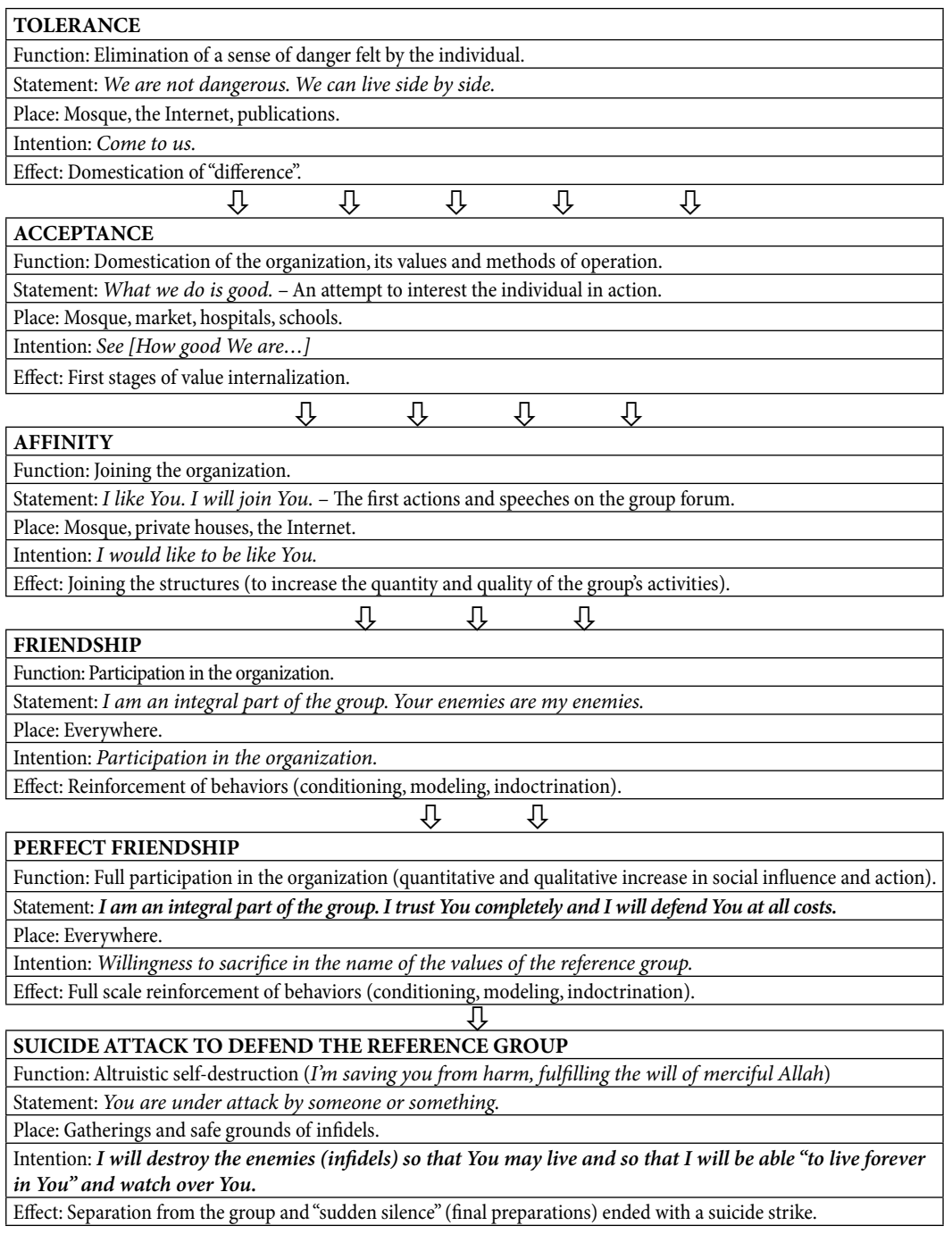

Model 1. An "Altruistic" Terrorist Model ("It takes only one step to move from love to hate") Based on psychosocial communication levels between the Individual and his/her reference group/organization.

Source: Author's own work. Note: Due to processual nature of human life and basic conditions of this model it is impossible that every man who will start modeling his/her behavior according to this model will end as a suicide bomber - furthermore drop-outs are normal part in the process of communication between individual and his/ her reference group/organization. 


\section{CONCLUSIONS}

Suicide terrorism is a very interesting and broad subject of research. To date, numerous studies have endeavored to explain the determinants of this phenomenon and ways to prevent it. As the existing methods reviewed in this paper have ultimately failed to provide a successful explanation of suicide terrorism and its dynamic nature, an altruistic suicide terrorist model has been proposed. The main advantage of the developed model is a new perspective on understanding (would-be suicide) terrorist motivation in members of terrorist organizations; on the other hand, the model may be less useful in addressing the problem of Islamic lone-wolf suicide motivation. As a result, an empirical evaluation of the model is required.

\section{REFERENCES:}

Agar, M. (1996). The Professional Stranger: An Informal Introduction to Ethnography. Cambridge, Mas.: Academic Press.

Aktan, H. (2007). Działania terrorystyczne i zamachy samobójcze w świetle Koranu i tradycji Proroka. In: E. Çapan (ed.). Terroryzm i zamachy samobójcze. Muzułmański punkt widzenia (pp. 41-62). Warszawa: Wydawnictwo Akademickie DIALOG.

Alexander, R.D. (1987). The Biology of Moral Systems. New York: Aldine de Guyer.

Ardila, R. (2002). The Psychology of the Terrorist: Behavioral Perspectives. In: Ch.E. Stout (ed.). The Psychology of Terrorism. Vol. 1: A Public Understanding (pp. 9-15). Westport, CT-London: Praeger.

Aronson, E. (2011). The Social Animal (11 $1^{\text {th }}$ ed.). New York: Worth/Freeman.

Aronson, E., Wilson, T.D., \& Akert, R.M. (2010). Social Psychology ( $7^{\text {th }}$ ed.). Upper Saddle River, NY: Prentice Hall.

Aronson, E., Wilson, T.D., Akert, R.M., \& Sommers, S.R. (2015). Social Psychology (9 $9^{\text {th }}$ ed.). New York: Prentice Hall.

Austin, W.G., \& Worchel, S. (eds.). (1979). The Social Psychology of Intergroup Relations. Monterey, CA: Brooks/Cole.

Axelrod, R. (1984). The Evolution of Cooperation. New York: Basic Books.

Bales, R.F. (1950). Interaction Process Analysis: A Method for the Study of Small Groups. Cambridge, MA: Wesley-Addison Press.

Bandura, A. (1973). Aggression: A Social Learning Analysis. Englewood Cliffs: Prentice-Hall. Bandura, A. (1986). Social Foundations of Thought and Action: A Social Cognitive Theory. Englewood Cliffs: Prentice-Hall.

Barker, E. (1990). New Religious Movements: A Practical Introduction. London: Bernan Press.

Batson, Ch.D. (1991). The Altruism Question: Towards a Socio-Psychological Answer. New York-London: Psychology Press. 
Batson, Ch.D. (2011). Altruism in Humans. New York, NY: Oxford University Press. Bauman, Z. (2000). Liquid Modernity. Cambridge: Polity Press.

Berkowitz, L. (1989). Frustration-Aggression Hypothesis: Examination and Reformulation. Psychological Bulletin, 106(1), 59-73. DOI: 10.1037/0033-2909.106.1.59.

Bolechów, B. (2002). Terroryzm w świecie podwubiegunowym. Przewartościowania $i$ kontynuacje. Toruń: Adam Marszałek.

Bolechów, B. (2010). Terroryzm. Aktorzy, statyści, widownie. Warszawa: Wydawnictwo Naukowe PWN.

Böllinger, L. (1981). Die Entwicklung zu terroristischem Handeln als psychosozialer Prozess: Begegnungen mit Beteiligte. In: H. Jäger, G. Schmidtchen, \& L. Süllwood (eds.). Analysen zum Terrorismus. Vol. 2: Lebenslauf-Analysen (pp. 175-231). Opladen: Westdeutscher Verlag.

Borum, R. (2003). Understanding the Terrorist Mindset. FBI Law Enforcement Bulletin, 72(7), 7-10.

Brewer, M.B. (1999). The Psychology of Prejudice: Ingroup Love or Outgroup Hate? Journal of Social Issues, 55(3), 429-444. DOI: 10.1111/0022-4537.00126.

Brown, R. (2001). Group Processes: Dynamics within and between Groups. Oxford, UK, Malden, MA: Blackwell Publishers.

Caracci, G. (2002). Cultural and Contextual Aspects of Terrorism. In: Ch.E. Stout (ed.). The Psychology of Terrorism. Vol. 3: Theoretical Understandings and Perspectives (pp. 57-83). Westport, CT-London: Praeger.

Cialdini, R.B. (2007). Influence: The Psychology of Persuasion. New York: Collins.

Clarke, P.B. (2006). New Religions in Global Perspective: A Study of Religious Change in the Modern World. New York: Routledge.

Cooley, Ch.H. (1902). Human Nature and the Social Order. New York: Charles Scribner's Sons.

Cooper, H.H.A. (1977). What Is a Terrorist? A Psychological Perspective. Legal Medical Quarterly, 1, 16-32.

Cooper, H.H.A. (1978). Psychopath as terrorist, Legal Medical Quarterly, 2, 253-262.

Crayton, J.W. (1983). Terrorism and Psychology of the Self. In: L.Z. Freedman, \& Y. Alexander (eds.). Perspectives on Terrorism (pp. 33-41). Wilmington: Scholarly Resource.

Crelinsten, R.D. (1988). The Internal Dynamics of the FLQ during the October Crisis of 1970. In: D. Rapoport (ed.). Inside Terrorist Organizations (pp. 59-89). New York: Columbia University Press.

Crenshaw, M. (1981). The Causes of Terrorism. Comparative Politics, 13(4), 379-399.

Crenshaw, M. (1986). The Psychology of Political Terrorism. In: M.G. Hermann (ed.). Political Psychology: Contemporary Problems and Issues (pp. 379-413). San Francisco: Jossey-Bass.

Davies, J.C. (1962). Toward a Theory of Revolution. American Sociological Review, 27(1), 5-19. DOI: $10.2307 / 2089714$.

Dawkins, R. (1976). Selfish Gene. Oxford: Oxford University Press.

DeLong-Bas, N.J. (2004). Wahhabi Islam: From Revival and Reform to Global Jihad. Oxford: Oxford University Press. 
Doise, W., \& Palmonari, A. (eds.). (1984). Social Interaction in Individual Development. Cambridge: Cambridge University Press.

Drummond, J.T. (2002). From the Northwest Imperative to Global Jihad: Social Psychological Aspects of the Construction of the Enemy, Political Violence, and Terror. In: Ch.E. Stout (ed.). The Psychology of Terrorism. Vol. 1: A Public Understanding (pp. 49-95). Westport, CT-London: Praeger.

Durkheim, E. (1897). Le Suicide: Étude de sociologie. Paris: Félix Alcan.

Durkheim, E. (2011). Samobójstwo. Studium z socjologii. Warszawa: Oficyna Naukowa. Ellul, J. (1965). Propaganda: The Formation of Men's Attitudes. New York: Knopf.

Erikson, E.H. (1950). Childhood and Society. New York: Norton \& Co.

Erikson, E.H. (1968). Identity, Youth and Crisis. New York: Norton \& Co.

Erikson, E.H. \& Erikson, J.M. (1997). The Life Cycle Completed. Extended Version. New York: Norton.

Ferracuti, F., \& Bruno, F. (1981). Psychiatric Aspects of Terrorism in Italy. In: I.L. BarakGlantz, \& C.R., Huff (eds.). The Mad, the Bad and the Different: Essays in Honor of Simon Dinitz (pp. 199-213). Lexington: Lexington Books.

Ferracuti, F. (1982). A sociopsychiatric interpretation of terrorism. The Annals of the American Academy of Political and Social Science, 463(1), 129-140.

Festinger, L., Riecken, H., \& Schachter, S. (1956). When Prophecy Fails: A Social and Psychological Study of a Modern Group That Predicted the Destruction of the World. Minneapolis: University of Minnesota Press.

Fetscher, I., \& Rohrmoser, G. (1981). Analysen zum Terrorismus. Vol. 1: Ideologien und Strategien. Opladen: Westdeutscher Verlag.

Fetterman, D. (2009). Ethnography: Step-by-Step ( $3^{\text {rd }}$ ed.). Thousand Oaks CA: SAGE.

Feuer, L.S. (1969). The Conflict of Generations: The Character and Significance of Student Movements. New York: Basic Books.

Gallimore, T. (2002). Unresolved Trauma: Fuel for the Cycle of Violence and Terrorism. In: Ch.E. Stout (ed.). The Psychology of Terrorism. Vol. 2: Clinical Aspects and Responses (pp. 143-168). Westport, CT-London: Praeger.

Ganor, B. (2005). The Counter-Terrorism Puzzle: A Guide for Decision Makers. New Brunswick-London: Transaction Publishers.

Gaylin, W. (2003). Hatred: The Psychological Descent into Violence. New York: Public Affairs.

Geertz, C. (1973). The Interpretation of Cultures. New York: Basic Books.

Giddens, A. (2004). Socjologia. Warszawa: WN PWN.

Girard, R. (2004). Les origines de la culture: Entretiens avec Pierpaolo Antonello et João de Castro Rocha. Paris: Desclée de Brouwer.

Goertzel, T.G. (2002). Terrorist Beliefs and Terrorist Lives. In: Ch.E. Stout (ed.). The Psychology of Terrorism. Vol. 1: A Public Understanding (pp. 97-111). Westport, CT-London: Praeger.

Güneş, A. (2007). Prawo muzułmańskie: przegląd zasad dotyczących wojny. In: E. Çapan (ed.). Terroryzm i zamachy samobójcze. Muzułmański punkt widzenia (pp. 140-152). Warszawa: Wydawnictwo Akademickie DIALOG. 
Gupta, D.K. (2005). Exploring Roots of Terrorism. In: T. Bjørgo (ed.). Root Causes of Terrorism: Myths, Reality and Ways Forward (pp. 16-32). London-New York: Routledge.

Gurr, T.R. (1970). Why Men Rebel. Princeton: Princeton University Press.

Hacker, F.J. (1983). Dialectical Interrelationships of Personal and Political Factors in Terrorism. In: L.Z. Freedman, \& Y. Alexander (eds.). Perspectives on Terrorism (pp. 19-32). Wilmington: Scholarly Resources.

Hamden, R.H. (2002). The Retributional Terrorist: Type 4. In: Ch.E. Stout (ed.). The Psychology of Terrorism. Vol. 2: Clinical Aspects and Responses (pp. 165-192). Westport, CT-London: Praeger.

Hamilton, W. (1964). The Genetical Evolution of Social Behavior: I, II. Journal of Theoretical Biology, 7, 1-16, 17-52.

Hammersley, M., \& Atkinson, P. (2007). Ethnography: Principles in Practice ( $3^{\text {rd }}$ ed.). London: Routledge.

Harris, J.R. (1998). The Nurture Assumption: Why Children Turn Out the Way They Do? New York: The Free Press.

Hassan, S. (1988). Combatting Cult Mind Control. Rochester, VT: Park Street Press.

Hoffer, E. (1981). The True Believer: Thoughts on the Nature of Mass Movements. New York: Perennial Library.

Horgan, J. (2003). The Search for the Terrorist Personality. In: A. Silke (ed.). Terrorists, Victims and Society: Psychological Perspectives on Terrorism and its Consequences (pp. 3-29). Chichester-Hoboken: Wiley Series in Psychology of Crime, Policing and Law. DOI: 10.1002/9780470713600.ch1.

Horgan, J. (2005). Psychology of Terrorism. London: Routledge.

Horgan, J. (2008). Psychologia terroryzmu. Warszawa: WN PWN.

Horgan, J. (2014). Psychology of Terrorism (revised and updated $2^{\text {nd }}$ ed.). London: Routledge.

Hubbard, D.G. (1983). The Psychodynamics of Terrorism. In: Y. Alexander, \& T. Adeniran (eds.). International Violence (pp. 45-53). New York: Praeger.

Hurrelmann, K. (1989). Social Structure and Personality Development: The Individual as a Productive Processor of Reality. Cambridge: Cambridge University Press.

Johnson, P.W., \& Feldman, T.B. (1992). Personality Types and Terrorism: Self-psychology Perspectives. Forensic Reports, 5(4), 293-303.

Karolczak, K. (2010). Terroryzm. Nowy paradygmat wojny w XXI wieku. Warszawa: Niemczyk i Wspólnicy.

Kohut, H. (1971). The Analysis of the Self: A Systematic Approach to the Psychoanalytic Treatment of Narcissistic Personality Disorders. New York: International Universities Press.

Kottak, C.P. (2013). Mirror on Humanity: A Concise Introduction to General Anthropology. New York: McGraw-Hill.

Kressel, N.J. (2002). Mass Hate: The Global Rise of Genocide and Terror. New York: Westview.

Kropotkin, P. (1902). Mutual Aid: A Factor of Evolution. London: Heinemann.

Laqueur, W. (2001). The New Terrorism: Fanaticism and the Arms of Mass Destruction. London: Phoenix Press. 
Lawal, O.A. (2002). Social-Psychological Considerations in the Emergence and Growth of Terrorism. In: Ch. E. Stout (ed.). The Psychology of Terrorism. Vol. 4: Programs and Practices in Response and Prevention (pp. 23-32). Westport, CT-London, Praeger.

Lerner, M.J. (1980). The Belief in a Just World: A Fundamental Delusion. New York: Plenum Press.

Levine, S. (1999). Youths in Terroristic Groups, Gangs and Cults: The Allure, the Animus, and the Alienation. Psychiatric Annals, 29, 342-349. DOI: 10.3928/0048-571319990601-08.

Lombroso, C. (1870). Studi clinici ed esperimentali sulla natura, causa e terapia della pellagra. Milano: G. Bernardoni.

Marcus, G.E., \& Fischer, M.M.J. (1986). Anthropology as Cultural Critique: An Experimental Moment in the Human Sciences. Chicago: University of Chicago Press.

McCauley, C.R., \& Segal, C.R. (1987). Social Psychology of Terrorist Groups. In: C. Hendrick (ed.). Review of Personality and Social Psychology. Vol. 9: Group Processes and Intergroup Relations (pp. 231-256). Thousand Oaks, CA: SAGE Publications.

Mead, G.H. (1934). Mind, Self, and Society. Chicago: University of Chicago Press.

Meerloo, J. (1956). The Rape of the Mind: The Psychology of Thought Control, Menticide, and Brainwashing. Cleveland: World Pub. Co.

Merton, R.K. (1968[1949]). Social Theory and Social Structure. New York: The Free Press. Moghaddam, F.M. (2005). The Staircase to Terrorism: A Psychological Exploration. American Psychologist, 60(2), 161-169.

Moghaddam, F.M. (2006). From the Terrorists' Point of View: What They Experience and Why They Come to Destroy? Westport, CT-London: Praeger.

Moghaddam, F.M., \& Harré, R. (1996). Psychological Limits to Political Revolutions: An Application of Social Reduction Theory. In: E. Hasselberg, L. Martienssen, \& F. Radtke (eds.). Der Dialogbegriff am Ende des 20. Jahrhunderts (pp. 230-240). Berlin: Hegel Institute.

Morf, G. (1970). Terror in Quebec - Case Studies of the FLQ. Toronto: Clark, Irwin \& Company.

Münkler, H. (2004). The New Wars. London: Wiley.

Ochs, E. (1988). Culture and Language Development: Language Acquisition and Language Socialization in a Samoan Village. Cambridge: Cambridge University Press.

Oliner, S.P., \& Oliner, P.M. (1995). Towards a Caring Society: Ideas into Action. Westport, CT: Praeger.

Olweean, S.S. (2002). Psychological Concepts of "the Other": Embracing the Compass of the Self. In: Ch.E. Stout (ed.). The Psychology of Terrorism. Vol. 1: A Public Understanding (pp. 113-128). Westport, Conn.-London: Praeger.

Oord, T. (2004). Science of Love: The Wisdom of Well-Being. Philadelphia: Templeton Foundation Press.

Oord, T. (2007). The Altruism Reader: Selections from Writings on Love, Religion, and Science. Philadelphia: Templeton Foundation Press.

Oord, T. (2010). Defining Love: A Philosophical Scientific, and Theological Engagement. Grand Rapids: Brazos Press. 
Oots, K.L., \& Wiegele, T. (1986). Terrorist and Victim: Psychiatric and Physiological Approaches from a Social Science Perspective. Studies in Conflict and Terrorism, 8(1), 1-32. DOI: 10.1080/10576108608435592.

Parsons, T. (1964). Social Structure and Personality. New York: The Free Press.

Pearlstein, R.M. (1991). The Mind of the Political Terrorist. Wilmington: SR Books.

Perlman, D. (2002). Intersubjective Dimensions of Terrorism and its Transcendence. In: Ch.E. Stout (ed.). The Psychology of Terrorism. Vol. 1: A Public Understanding (pp. 19-31). Westport, CT-London: Praeger.

Post, J.M. (2007). The Mind of the Terrorist: The Psychology of Terrorism from the IRA to Al-Qaeda. New York: Palgrave Macmillan.

Post, J.M., Sprinzak, E., \& Denny, L.M. (2003). The Terrorists in Their Own Words: Interviews with Thirty-Five Incarcerated Middle Eastern Terrorists. Terrorism and Political Violence, 15(1), 171-184.

Rapoport, D. (2004). The Four Waves of Modern Terrorism. In: A.K. Cronin, \& J.M. Ludes (eds.). Attacking Terrorism: Elements of a Grand Strategy (pp. 46-73). Washington, D.C.: Georgetown University Press.

Reid, W.H. (2002). Controlling Political Terrorism: Practicality, Not Psychology. In: Ch.E. Stout (ed.). The Psychology of Terrorism. Vol. 1: A Public Understanding (pp. 1-8). Westport, CT-London: Praeger.

Robins, R.M., \& Post, J.M. (1997). Political Paranoia: The Psychopolitics of Hatred. New Haven: Yale University Press.

Rothman, S., \& Lichter, R.S. (1982). Roots of Radicalism: Jews, Christians and the New Left. New York: Oxford University Press.

Sageman, M. (2004). Understanding Terror Networks. New York: University of Pennsylvania Press.

Saliba, J.A. (2003). Understanding New Religious Movements. Walnut Creek, Lanham: AltaMira Press.

Sandler, T., \& Arce, D.G. (2003). Terrorism and Game Theory. Simulation and Gaming, 34(3), 319-337. DOI: 10.1177/1046878103255492.

Schieffelin, B. (1990). The Give and Take of Everyday Life: Language Socialization of Kaluli Children. Cambridge: Cambridge University Press.

Schieffelin, B., Woolard, K.A., \& Kroskrity, P.V. (eds.). (1998). Language Ideologies: Practice and Theory. Oxford: Oxford University Press.

Seed, D. (2004). Brainwashing: A Study in Cold War Demonology. Kent, OH: Kent State University Press.

Selengut, Ch. (2003). Sacred Fury: Understanding Religious Violence. Walnut Creek: Alta Mira Press.

Shaw, E.D. (1986). Political Terrorists: Dangers of Diagnosis and an Alternative to the Psychopathology Model. International Journal of Law and Psychiatry, 8(3), 359-368. DOI: $10.1016 / 0160-2527(86) 90066-X$.

Sherif, M. (1966). In Common Predicament: Social Psychology of Intergroup Conflict and Cooperation. Boston: Houghton Mifflin. 
Singer, M.T., \& Lalich, J. (2003). Cults in Our Midst: The Hidden Menace in Our Everyday Lives. San Francisco, CA: Jossey-Bass.

Smith, D.L. (2011). Najbardziej niebezpieczne ze zwierząt. Natura ludzka i przyczyny wojen. Warszawa-Stare Groszki: Wydawnictwo CiS.

Sorokin, P.A. (1925). Sociology of Revolution. Philadelphia, London: J.B. Lippincott Company.

Sprinzak, E. (1998). The Psychopolitical Formation of Extreme Left Terrorism in a Democracy: The Case of the Weathermen. In: W. Reich (ed.). Origins of Terrorism: Psychologies, Ideologies, Theologies, States of Mind (pp. 65-85). Washington, D.C.: Woodrow Wilson Center Press.

Stark, R., \& Bainbridge, W.S. (1979). On Churches, Sects, and Cults: Preliminary Concepts for a Theory of Religious Movements. Journal for the Scientific Study of Religion, 18(2), 117-133.

Stark, R., \& Bainbridge, W.S. (1985). The Future of Religion: Secularization, Revival, and Cult Formation. Berkeley and Los Angeles: University of California Press.

Staub, E. (2004). Understanding and Responding to Group Violence: Genocide, Mass Killing, and Terrorism. In: F.M. Moghaddam, \& A.J. Marsella (eds.). Understanding Terrorism: Psychosocial Roots, Consequences and Interventions (pp. 151-168). Washington, D.C.: American Psychological Association. DOI: 10.1037/10621-007.

Stern, J. (2003). Terror in the Name of God: Why Religious Militants Kill. New York: Harper Collins.

Stevens, M.J. (2002). The Unanticipated Consequences of Globalization: Contextualizing Terrorism. In: Ch.E. Stout (ed.). The Psychology of Terrorism. Vol. 3: Theoretical Understandings and Perspectives (pp. 31-54). Westport, CT-London: Praeger.

Stirling, M.C. (2004). Violent Religion: René Girard's Theory of Culture. In: J.H. Ellens (ed.). Destructive Power of Religion. Vol. 2: Religion, Psychology and Violence (pp. 12-21). London-Westport, CT: Praeger.

Stocking, G.W. (1968). Race, Culture and Evolution: Essays in the History of Anthropology. London: The Free Press.

Storr, A. (1997). Feet of Clay: Saints, Sinners, and Madmen. A Study of Gurus. New York: The Free Press.

Sztompka, P. (1999). Trust: A Sociological Theory. Cambridge: Cambridge University Press. Sztompka, P. (2002). Socjologia. Analiza społeczeństwa. Kraków: Wydawnictwo ZNAK. Tajfel, H., \& Turner, J.C. (1986). The Social Identity Theory of Intergroup Behavior. In: S. Worchel, \& W.G. Austin (eds.). Psychology of Intergroup Relations (pp. 7-24). Chicago: Nelson-Hall.

Taylor, D.M., \& Louis, W. (2004). Terrorism and the Quest for Identity. In: F.M. Moghaddam, \& A.J. Marsella (eds.). Understanding Terrorism: Psychosocial Roots, Consequences and Interventions (pp. 169-186). Washington, D.C.: American Psychological Association.

Taylor, K.E. (2004). Brainwashing: The Science of Thought Control. Oxford, New York: Oxford University Press.

Taylor, M. (1988). The Terrorist. London: Brassey's. 
Thouless, R.H. (1953). Straight and Crooked Thinking. New York: Simon \& Schuster.

Toch, H. (1965). The Social Psychology of Social Movements. Indianapolis: Bobbs-Merrill Company.

Trivers, R.L. (1971). The Evolution of Reciprocal Altruism. Quarterly Review of Biology, $46(1), 35-57$.

Turner, J.H. (1994). Sociology: Concepts and Uses. New York: McGraw-Hill.

Tylor, E.B. (1871). Primitive Culture. Vols. 1-2. London: John Murray.

Tylor, E.B. (1881). Anthropology: An Introduction to the Study of Man and Civilization. London: Macmillan and Co.

Van Maanen, J. (1988). Tales of the Field: On Writing Ethnography. Chicago: University of Chicago Press.

Vertigans, S. (2011). The Sociology of Terrorism: People, Places and Processes. LondonNew York: Routledge.

Volkan, V.D. (1988). The Need to Have Enemies and Allies: From Clinical Practice to International Relationships. Northvale: Jason Aronson.

Volkan, V.D. (1992). Ethnonationalistic Rituals: An Introduction. Mind and Human Interaction, 4(1), 3-19.

Volkan, V.D. (1997). Bloodline: From Ethnic Pride to Ethnic Terrorism. New York: Farrar, Strauss and Giroux.

Vygotsky, L.S. (1978). Mind in Society: The Development of Higher Psychological Processes. Cambridge, MA: Harvard University Press.

Waldmann, P. (2005). Social-Revolutionary Terrorism in Latin America and Europe. In: T. Bjørgo (ed.). Root Causes of Terrorism: Myths, Reality and Ways Forward (pp. 154-163). London-New York: Routledge.

Weinberg, L., \& Eubank, W.L. (1994). Cultural Differences in the Behavior of Terrorists. Terrorism and Political Violence, 6(1), 1-18. DOI: 10.1080/09546559408427237.

White, G. (1977). Socialisation. London: Longman.

Wilson, B.R. (1961). Sects and Society: A Sociological Study of the Elim Tabernacle, Christian Science, and Christadelphians. Berkeley-Los Angeles: University of California Press.

Wilson, B.R. (1990). The Social Dimensions of Sectarianism: Sects and New Religious Movements in Contemporary Society. Oxford: Clarendon Press.

Wilson, B.R., \& Cresswell, J. (eds.). (1999). New Religious Movements: Challenge and Response. London: Routledge.

Wright, R. (1995). The Moral Animal: Why We Are, the Way We Are: The New Science of Evolutionary Psychology. New York: Vintage Books.

Yüceoğlu, H. (2007). Definicja męczeństwa. Czy terrorysta może być męczennikiem? In: E. Çapan (ed.). Terroryzm i zamachy samobójcze. Muzułmański punkt widzenia (pp. 105-121). Warszawa: Wydawnictwo Akademickie DIALOG.

Zimny, M. (2006). Terroryzm samobójczy. Warszawa: Dom Wydawniczy BELLONA. Zimny, M. (2017). Terroryzm samobójczy. Fakty, geneza, analiza. Warszawa: Difin SA. 